University of Nebraska - Lincoln

DigitalCommons@University of Nebraska - Lincoln

Papers in the Earth and Atmospheric Sciences Earth and Atmospheric Sciences, Department

5-15-2003

\title{
A Vegetation and Fire History of Lake Titicaca since the Last Glacial Maximum
}

Gina M. Paduano

Florida Institute of Technology, Melbourne, FL

Mark B. Bush

Florida Institute of Technology

Paul A. Baker

Florida Institute of Technology, pbaker@duke.edu

Sherilyn C. Fritz

University of Nebraska-Lincoln, sfritz2@unl.edu

Geoffrey O. Seltzer

Syracuse University

Follow this and additional works at: https://digitalcommons.unl.edu/geosciencefacpub

Part of the Earth Sciences Commons

Paduano, Gina M.; Bush, Mark B.; Baker, Paul A.; Fritz, Sherilyn C.; and Seltzer, Geoffrey O., "A Vegetation and Fire History of Lake Titicaca since the Last Glacial Maximum" (2003). Papers in the Earth and Atmospheric Sciences. 36.

https://digitalcommons.unl.edu/geosciencefacpub/36

This Article is brought to you for free and open access by the Earth and Atmospheric Sciences, Department of at DigitalCommons@University of Nebraska - Lincoln. It has been accepted for inclusion in Papers in the Earth and Atmospheric Sciences by an authorized administrator of DigitalCommons@University of Nebraska - Lincoln. 
Published in Palaeogeography, Palaeoclimatology, Palaeoecology 194:1-3 (May 15, 2003), pp. 259-279; doi:10.1016/S0031-0182(03)00281-5 Special issue on "Late-quaternary palaeoclimates of the southern tropical Andes and adjacent regions.” Copyright (c) 2003 Elsevier Science B.V. Used by permission.

http://www.sciencedirect.com/science/journal/00310182

Accepted January 17, 2003; published online April 3, 2003.

\title{
A Vegetation and Fire History of Lake Titicaca since the Last Glacial Maximum
}

\author{
Gina M. Paduano ${ }^{\mathrm{a}}$, Mark B. Bush ${ }^{\mathrm{a}, *}$, Paul A. Baker ${ }^{\mathrm{b}}$, Sherilyn C. Fritz ${ }^{\mathrm{c}}$, \\ and Geoffrey O. Seltzer ${ }^{\mathrm{d}}$ \\ a Department of Biological Sciences, Florida Institute of Technology, Melbourne, FL 32901, USA \\ b Department of Geology, Duke University, Durham, NC 27708, USA \\ c Department of Geosciences and School of Biological Sciences, \\ University of Nebraska-Lincoln, Lincoln, NE 68588, USA \\ ${ }^{\mathrm{d}}$ Department of Earth Sciences, Syracuse University, \\ Syracuse, NY 13244, USA \\ * Corresponding author-fax 321 674-7238
}

\begin{abstract}
Fine-resolution fossil pollen and charcoal analyses reconstruct a vegetation and fire history in the area surrounding Lake Titicaca (3810 m, Peru/Bolivia) since ca. 27,500 cal yr BP (hereafter BP). Time control was based on 26 accelerator mass spectrometer (AMS) radiocarbon dates. Seventeen AMS dates and 155 pollen and charcoal samples between ca. 17,500 BP and ca. 3,100 BP allow a centennial-scale reconstruction of deglacial and early- to mid-Holocene events. Local and regional fire signals were based on the separation of two charcoal size fractions, $\geq 180 \mu \mathrm{m}$ and $179-65 \mu \mathrm{m}$. Charcoal abundance correlated closely with the proportion of woody taxa present in the pollen spectra. Little or no pollen was detected in the sedimentary record prior to ca. 21,000 BP. Very cold climatic conditions prevailed, with temperatures suggested to be at least $5-8^{\circ} \mathrm{C}$ cooler than present. Increases in pollen concentration suggest initial warming at ca. 21,000 BP with a more significant transition toward deglaciation ca. 17,700 BP. Between 17,700 BP and 13,700 BP, puna brava is progressively replaced by puna and sub-puna elements. The most significant changes between the Pleistocene and the Holocene floras were largely complete by 13,700 BP, providing an effective onset of near-modern conditions markedly earlier than in other Andean records. Fire first occurs in the catchment at ca. 17,700 BP and becomes progressively more important as fuel loads increase. No evidence is found of a rapid cooling and warming coincident with the Younger Dryas chron. A dry event between ca. 9,000 BP and 3,100 BP, with a peak between 6,000 and 4,000 BP, is inferred from changes in the composition of aquatics, and the marsh community as pollen of Cyperaceae is replaced by Poaceae, Apiaceae, Plantago and the shrub Polylepis. Human disturbance of the landscape is evident in the pollen spectra after ca. 3,100 BP with the appearance of weed species.
\end{abstract}

Keywords: Andes, climatic change, deglaciation, fire, Holocene, Lake Titicaca, Pleistocene, pollen 


\section{Introduction}

The vegetation of the high Andes and the Altiplano has responded to climatic change throughout the Quaternary (Binford et al., 1996; Graf, 1981; Hansen and Rodbell, 1995; Hansen et al., 1984; Hansen et al., 1994; Kuhry, 1988; Moreno, 2000; Moreno et al., 1999; Salgado-Labouriau et al., 1977; Salgado-Labouriau et al., 1988; Van der Hammen et al., 1980/1981; Van der Hammen and González, 1959 and Ybert, 1988). Due to the steepness of Andean slopes and the short migratory distances, Andean plant migrations provide a sensitive paleothermometer. Major glacial events are faithfully represented in changing plant associations (e.g. Colinvaux et al., 1997; Hansen et al., 1984; Hooghiemstra, 1989 and Van der Hammen, 1974). However, inconsistencies exist among records, particularly with regard to the nature of the Younger Dryas time period (e.g. Clapperton, 1993 and Heine, 1993), the Last Glacial Maximum (LGM), and the mid-Holocene (Betancourt et al., 2000; Baker et al., 2001a and Baker et al., 2001b). This study was undertaken to consider apparent controversies in paleoecological reconstructions through fine-scale analysis of fossil pollen and charcoal from Lake Titicaca.

Earlier studies by Ybert, 1988 and Ybert, 1992 describe the vegetation and lake level history of Lake Titicaca using pollen, spores, and aquatic algae and macrophytes. Ybert raised a $5 \mathrm{~m}$ long core from beneath $<20 \mathrm{~m}$ water in the Lago Wiñaymarka sub-basin of Lake Titicaca. The basal age of the core (TD1) was estimated to be $>28,000$ cal yr BP (hereafter BP), but contained an apparent break in sedimentation between ca. 21,000 BP and ca. 8,500 BP (Wirrmann et al., 1992). A parallel core (TD) that included missing portions of TD1 was later analyzed to develop a more complete chronology (Ybert, 1992). Pollen and algal evidence from Lago Wiñaymarka suggests fluctuations in both temperature and lake level throughout the period of deglaciation and the Holocene. However, further work on a single, continuous sedimentary sequence including high-resolution chronologic control was needed to resolve the details of climatic change during deglaciation of the Altiplano.

\subsection{The study site}

Lake Titicaca is situated in the northern portion of the Bolivian Altiplano $\left(16-20^{\circ} \mathrm{S}, 65-69^{\circ} \mathrm{W}\right)$ at an elevation of 3,810 m above sea level (Figure 1). The lake encompasses approximately $8,500 \mathrm{~km}^{2}$ and functions as a nearly closed system (Dejoux and Iltis, 1992). Lake Titicaca is composed of two nearly separate basins, Lago Grande and Lago Wiñaymarka, which are connected via the Straits of Tiquina. Lago Grande is the deeper of the two basins with an average depth of $135 \mathrm{~m}$ and the deepest measured point of $284 \mathrm{~m}$ (Boulange and Aquize Jaen, 1981). The shallower Wiñaymarka basin has an average depth of $9 \mathrm{~m}$.

The Altiplano has a cold, semi-arid climate with mean annual temperatures between $7^{\circ} \mathrm{C}$ and $10^{\circ} \mathrm{C}$ reported for areas lying below 4,000 m elevation. Around Lake Titicaca the mean annual temperature is $8^{\circ} \mathrm{C}$ (Roche et al., 1992), with a mean daily temperature range of $15-20^{\circ} \mathrm{C}$. Between December and March the Altiplano experiences a distinct wet season, with $65-78 \%$ of the total annual precipitation falling in these four months (Roche et al., 1992). Average precipitation over the basin is $758 \mathrm{~mm} / \mathrm{yr}$, and the long-term average rainfall of Lago Grande is 889 $\mathrm{mm} / \mathrm{yr}$ (Roche et al., 1992). Lago Wiñaymarka is somewhat drier, receiving $829 \mathrm{~mm} / \mathrm{yr}$ (Roche et al., 1992). Factors that affect the water balance of the Altiplano include variations in the strength of the summer monsoon circulation, changes in the seasonal location of the Intertropical Convergence Zone and El Niño-Southern Oscillation (ENSO) events (Cerveny, 1999 and Curtis and Hastenrath, 1999). Strong El Niño years correlate with drought on the Altiplano (Roche et al., 1992).

Lake level is presently driven by the balance between precipitation and evaporative loss from the lake surface. Because annual evaporative loss from the lake surface is as much as $1,628 \mathrm{~mm}$, when precipitation is reduced lake level falls rapidly (Roche $e t$ al., 1992). During the relatively dry period of 19561987, evaporation accounted for $98.5 \%$ of the total water loss from Lake Titicaca; only $1.5 \%$ was exported via the Rio Desguadero (Carmouze and Aquize Jaen, 1981).

As a result of ENSO variability and irregular cycles of precipitation, lake level has fluctuated by as 


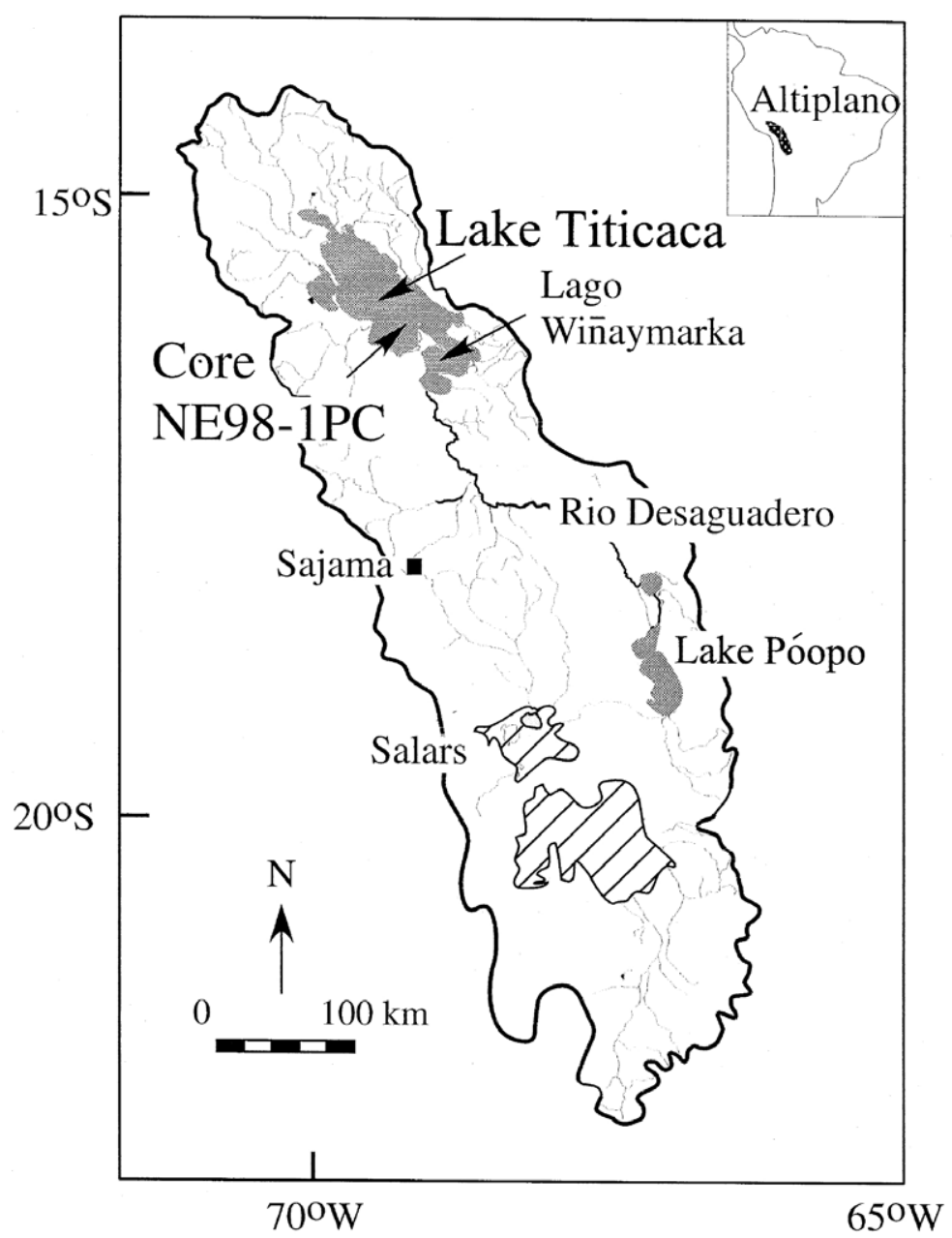

Figure 1. Sketch map showing the location of Lake Titicaca and the coring site for NE98-1PC and boxcore NE98-5BX (same location).

much as $6.37 \mathrm{~m}$ in the 20th century (Roche et al., 1992). Hence, lake level may be used as a sensitive proxy for changes in insolation, cloudiness, and rainfall.

Lake Titicaca lies close to the lower limit of puna vegetation which has been substantially altered by human activity. Troll (1968) and Graf (1981) conducted surveys around Titicaca to describe local vegetation boundaries (Table 1) and list some taxa that characterize the various biomes. From a palynological perspective puna, sub-puna, and Andean forest have been recognized in numerous previous studies, (e.g. Grabandt, 1995; Hansen et al., 1984). As superpuna contains many of the same families and genera as puna, it is best recognized by extremely low pollen concentrations derived from a sparse vegetation and high percentages of extraneous pollen blown upslope from the Andean forest (Hansen et al., 1984 and Colinvaux et al., 1997).

\section{Materials and methods}

A 10.60-m Kuhlenberg core (NE98-1PC) was raised in January, 1998 from beneath $152 \mathrm{~m}$ of water in Lago Grande at $16^{\circ} 08.004^{\prime} \mathrm{S}, 69^{\circ} 09.199^{\prime} \mathrm{W}$ (Baker et al., 2001b). A boxcore $1 \mathrm{~m}$ long, NE98-5BX, was raised close to core NE98-1PC. The two cores were cross-correlated by lithology and magnetic susceptibility, and overlapped at $62 \mathrm{~cm}$ depth in core NE98- 
Table 1. Montane plant communities, their vertical distribution, and characteristic taxa in southeastern Peru and northeastern Bolivia (after Troll, 1968; Graf, 1981)

\begin{tabular}{llc}
\hline Vegetation type & Vegetation description & Elevation (m) \\
\hline Puna brava & $\begin{array}{l}\text { Scattered Poaceae, Asteraceae, Brassicaceae. Family composition similar to } \\
\text { puna but sparser vegetation }\end{array}$ & $5,300-4,500$ \\
Puna & $\begin{array}{l}\text { Asteraceae, Brassicaceae, Gentianaceae, Plantago, Poaceae, Valerianaceae, } \\
\text { and other herbs and shrubs }\end{array}$ & $4,500-3,800 / 3,700$ \\
Shrub belt & $\begin{array}{l}\text { Greater diversity and density of shrubs, e.g. Polylepis Ericaceae, } \\
\text { Andean forest }\end{array}$ & $\begin{array}{l}\text { Melastomataceae, and ferns } \\
\text { Trees: e.g. Alnus, Podocarpus, Weinmannia, Myrtaceae, Clusiaceae }\end{array}$ \\
\hline
\end{tabular}

1PC. As the uppermost $62 \mathrm{~cm}$ was contained in the NE98-5BX boxcore all depths in NE98-1PC were increased by $62 \mathrm{~cm}$ to provide true depth below the mud/water interface.

Subsamples $\left(0.5 \mathrm{~cm}^{3}\right)$ were taken for pollen and charcoal preparation at 10 -cm intervals throughout core NE98-1PC. Additional samples were taken at 2$\mathrm{cm}$ intervals for the depths of $68 \mathrm{~cm}$ to $361 \mathrm{~cm}$ to provide fine temporal resolution from ca. 3,100 BP to ca. $17,500 \mathrm{BP}$. Nine samples were taken at $10-\mathrm{cm}$ intervals from core NE98-5BX, yielding a total of 230 samples.

Table 2. Results of AMS dating of bulk samples of sediment from Lake Titicaca, Peru/Bolivia

\begin{tabular}{|c|c|c|c|c|c|}
\hline Lab No. & $\begin{array}{l}\text { True total } \\
\text { depth }(\mathrm{cm})\end{array}$ & $\begin{array}{l}\text { Adjusted } \\
\text { depth (cm) }\end{array}$ & $\begin{array}{c}\text { Age } \\
\left({ }^{14} \mathrm{C} \text { yr BP }\right)\end{array}$ & $\begin{array}{l}\text { Range of } \\
\text { cal yr BP }\end{array}$ & $\begin{array}{l}\text { Median } \\
\text { cal yr BP }\end{array}$ \\
\hline NSRL-10400 & Box 5.0 & 5.0 & $690 \pm 50$ & $670-568$ & 657 \\
\hline NSRL-10401 & Box 81.0 & 81.0 & $3,370 \pm 60$ & $3,689-3,483$ & 3,612 \\
\hline CAMS-61618 & 48.4 & 110.4 & $5,170 \pm 40$ & $5,947-5,904$ & 5,922 \\
\hline OS-20098 & 74.5 & 136.5 & $5,550 \pm 40$ & $6,399-6,293$ & 6,308 \\
\hline CAMS-61621 & 88.0 & 150.0 & $6,060 \pm 84$ & $7,136-6,759$ & 6,815 \\
\hline NSRL-11190 & 100.0 & 162.0 & $5,820 \pm 50$ & $6,719-6,552$ & 6,651 \\
\hline NOSAMS-17920 & 134.5 & 196.5 & $7,240 \pm 50$ & $8,149-7,975$ & 8,099 \\
\hline CAMS-61623 & 144.1 & 206.1 & $7,730 \pm 50$ & $8,587-8,420$ & 8,503 \\
\hline CAMS-61626 & 156.0 & 218.0 & $8,430 \pm 50$ & $9,520-9,333$ & 9,472 \\
\hline NSRL-11191 & 171.0 & 233.0 & $8,830 \pm 45$ & $10,145-9,777$ & 9,893 \\
\hline NSRL-11192 & 188.0 & 250.0 & $9,340 \pm 50$ & $10,666-10,430$ & 10,557 \\
\hline NOSAMS-17921 & 194.5 & 256.5 & $10,050 \pm 50$ & $11,874-11,304$ & 11,492 \\
\hline CAMS-61629 & 214.5 & 276.5 & $10,480 \pm 50$ & $12,801-12,328$ & 12,482 \\
\hline NSRL-11193 & 216.0 & 278.0 & $10,400 \pm 70$ & $12,632-11,974$ & 12,337 \\
\hline CAMS-61632 & 237.5 & 299.5 & $11,030 \pm 50$ & $13,142-12,910$ & 13,009 \\
\hline NSRL-11194 & 241.0 & 303.0 & $10,970 \pm 55$ & $13,125-12,892$ & 12,988 \\
\hline NSRL-11195 & 252.0 & 314.0 & $11,250 \pm 55$ & 13,362-13,142 & 13,166 \\
\hline OS-26860 & 277.0 & 339.0 & $12,810 \pm 60$ & $15,635-14,601$ & 15,488 \\
\hline CAMS-61635 & 293.1 & 355.1 & $14,550 \pm 50$ & $17,684-17,174$ & 17,422 \\
\hline NSRL-14350 & 304.0 & 366.0 & $14,350 \pm 65$ & $17,453-16,946$ & 17,192 \\
\hline CAMS-61638 & 316.8 & 378.8 & $15,660 \pm 60$ & $19,055-18,465$ & 18,700 \\
\hline NOSAMS-17922 & 374.5 & 436.5 & $17,200 \pm 170$ & 20,899-20,153 & 20,472 \\
\hline NOSAMS-17923 & 454.5 & 516.5 & $18,900 \pm 170$ & $22,889-22,088$ & 22,428 \\
\hline NOSAMS-17925 & 618.5 & 680.5 & $20,900 \pm 190$ & NA & 24,632 \\
\hline NOSAMS-17296 & 620.0 & 682.0 & $21,100 \pm 120$ & NA & 25,012 \\
\hline OS-19773 & 804.5 & 866.5 & $23,400 \pm 250$ & NA & 27,522 \\
\hline
\end{tabular}

Cores dated were NE98-1PC and boxcore NE98-5BX. Calibration ages provided by Calib 4.3 (Stuiver and Reimer, 1993) and for samples $>20,265{ }^{14} \mathrm{C}$ BP using the algorithm provided by Bard (1998). 


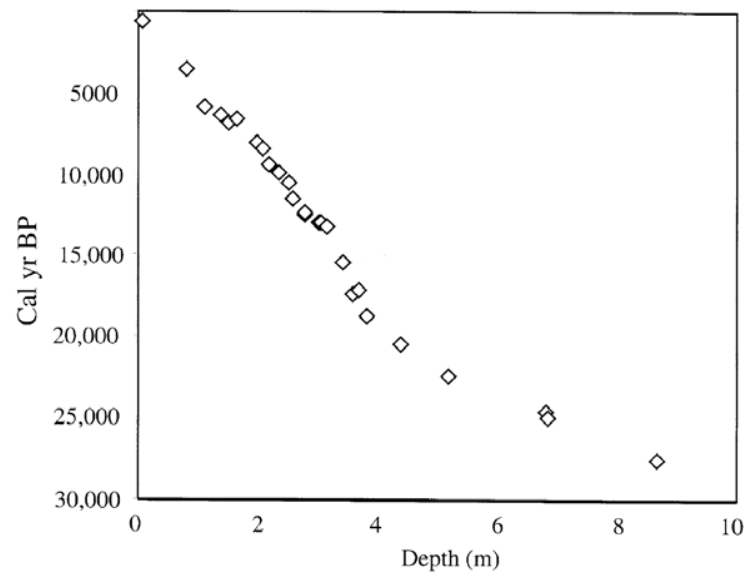

Figure 2. Calibrated radiocarbon chronology for sediments in core NE98-1PC and boxcore NE98-5BX from Lake Titicaca, Peru/Bolivia, based on 26 AMS dates. See Table 2 for ${ }^{14} \mathrm{C}$ values and calibration data.

Standard palynological techniques were employed to process the pollen samples (Faegri and Iversen, 1989). Samples were mounted in glycerol and analyzed with a Zeiss Axioskop photomicroscope at magnifications of $\times 400$ to $\times 1,000$. When possible, a minimum of 300 terrestrial pollen grains was counted for each interval. Spores and Pediastrum were not included in pollen sums and are expressed as a percentage of total pollen. Only 155 of the 230 intervals sampled sufficient (i.e. 300 grains) pollen for analysis and interpretation; pollen percentages for samples with less than 300 grains were based on counts of 2000 exotic Lycopodium. Pollen was identified with published photographs and keys (Heusser, 1971; Hooghiemstra, 1983; Hooghiemstra, 1984 and Markgraf and D’Antoni, 1978) and our reference collection of $>3000$ modern neotropical pollen types. Pollen grains of Poaceae were measured to the nearest micrometer and grouped into $2-\mu \mathrm{m}$ size class intervals (Bush, 1986).

Charcoal extraction followed Clark and Patterson (1997), but was modified by an additional treatment with $0.1 \mathrm{M} \mathrm{NO}_{4} \mathrm{P}_{2} \mathrm{O}_{7}$ to remove clay particles. The resulting slurry was washed through nested 180$\mu \mathrm{m}$ and $65-\mu \mathrm{m}$ mesh sieves, retaining particles $>180$ $\mu \mathrm{m}$ and $179-65 \mu \mathrm{m}$, respectively. Charcoal particles were identified and measured digitally using a Olym- pus stereo macroscope at magnifications of $\times 20$ (particles $\geq 180 \mu \mathrm{m}$ ) and $\times 32$ (particles 179-65 $\mu \mathrm{m}$ ). A video system and NIH image recognition software was used to determine the number of pixels occupied by the fragment and the exact surface area measurements of irregular shapes.

TILIA, TILIAGRAPH, and CONISS software were used to plot and zone the palynological data (Grimm, 1992). Further analysis of the ecological separation of zones was accomplished through detrended correspondence analysis (DCA) (Hill, 1979 and Ter Braak, 1988) of terrestrial pollen percentage data using PC ORD4 software (McCune and Mefford, 1999).

\section{Results}

\subsection{Stratigraphy and chronology}

Twenty-six accelerator mass spectrometer (AMS) radiocarbon dates for cores NE98-1PC and NE985BX (Table 2; Figure 2) were based on total organic carbon of bulk samples. Calibrations were performed with Calib 4.3 software for ages $<20,265{ }^{14} \mathrm{C}$ yr BP (Stuiver and Reimer, 1993); older dates were calibrated according to Bard (1998). Of four age reversals $(80 / 100 \mathrm{~cm}, 214.5 / 216 \mathrm{~cm}, 237.5 / 241 \mathrm{~cm}$, $293.1 / 304 \mathrm{~cm}$ ) the latter three fell within the range of calibrated ages reported, and the first fell within two standard deviations. Interpolated ages were based on the mean sedimentation rate calculated between dates. The depth-age model is similar to that of Baker et al. (2001a) but differs in that it includes some additional dates.

\subsection{Pollen zones}

\subsubsection{Pollen zone 1 (366-461 cm: ca. 21,000 to ca. $17,700 \mathrm{BP})$}

Pollen concentration is low $(\sim 300-\leq, 4,000$ grains/ $\mathrm{cm}^{3}$; Figure 3), and counts are based on fewer than 300 terrestrial pollen grains. Hence, zone 1 has some unusual components attributed to long-distance dispersal into a sparsely vegetated landscape. Pollen zone 1 is characterized primarily by puna elements, e.g. Brassicaceae, Cyperaceae, and Poaceae (Figure 4). Other important puna brava and puna taxa include 
a
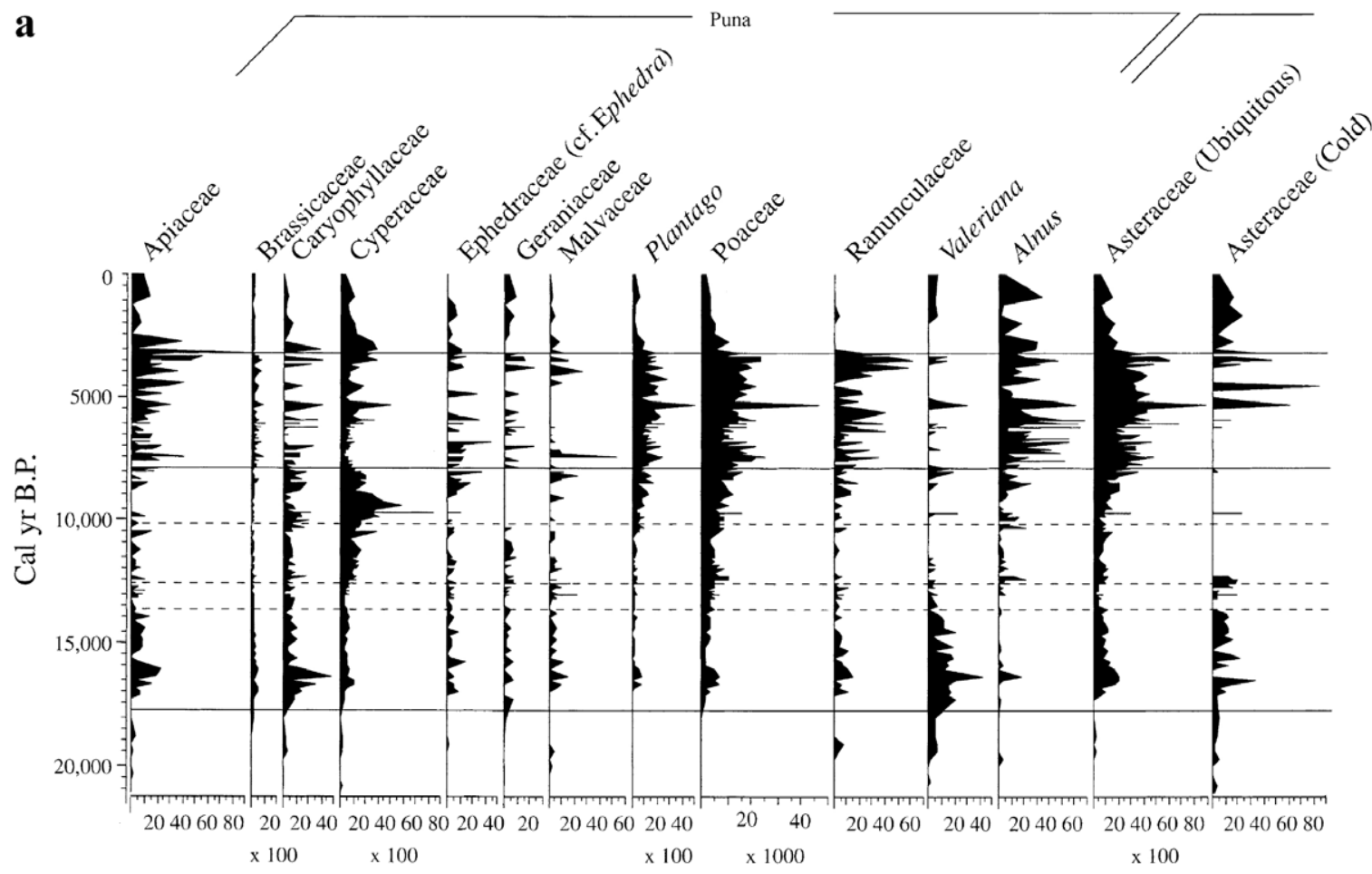

b

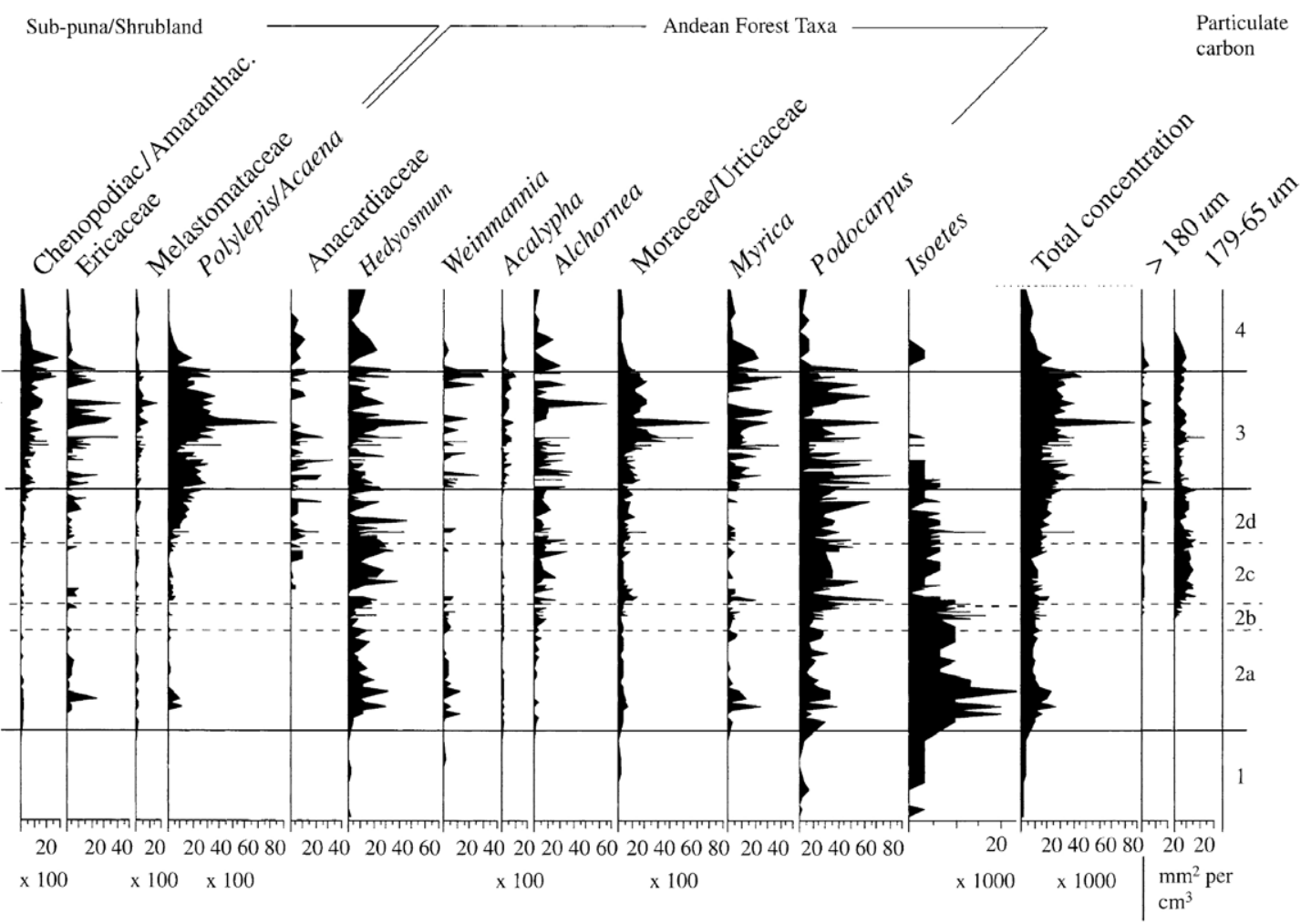


Apiaceae, Caryophyllaceae, Malvaceae, Plantago, Thalictrum and Valeriana. Sub-puna elements include Alnus, Chenopodiaceae/Amaranthaceae, Polylepis/Acaena, members of the Asteraceae and Melastomataceae. Pollen of Andean forest elements, such as Hedyosmum, Acalypha, Moraceae/Urticaceae, Podocarpus and Weinmannia, are present. Isoëtes spores are abundant throughout this zone but charcoal fragments are absent.

3.2.2. Pollen sub-zone $2 a$ (366-320 cm: ca. 17,700 to ca. $13,700 \mathrm{BP}$ )

In pollen zone 2 total pollen concentrations are higher than in zone 1 . Within pollen sub-zone 2a, pollen concentrations range from 10,000 to 27,000 grains $/ \mathrm{cm}^{3}$. Poaceae (35-48\%), Asteraceae (5-27\%), Cyperaceae (5-15\%), and Brassicaceae (5-12\%) account for $\sim 75 \%$ of the total pollen sum from subzone 2a. Puna and sub-puna taxa dominate. Other important components of the pollen spectra include Plantago, Valeriana, Polylepis/Acaena, Chenopodiaceae/Amaranthaceae, Moraceae/Urticaceae, and Podocarpus. Isoëtes spore percentages are high (25$60 \%)$. Three forms of Pediastrum $(\leq 30 \%)$ are present. Very low abundances of local and regional charcoal are recorded.

3.2.3. Pollen sub-zone $2 b$ (320-282 cm: ca. 13,700 to ca. $12,500 \mathrm{BP}$ )

The transition from pollen sub-zone $2 \mathrm{a}$ to pollen sub-zone $2 \mathrm{~b}$ is marked by a large increase in the percentage of Poaceae pollen (40-70\%), accompanied by decreased percentages of Asteraceae, Cyperaceae, and Brassicaceae pollen. Total pollen concentration is similar to the previous interval ranging between 10,000 and 20,000 grains/ $\mathrm{cm}^{3}$. Isoëtes spore percentages remain high, but somewhat lower than in the previous zone (60-48\%). Large peaks in abundance of Pediastrum types 2 and 3 characterize this zone. In the latter half of sub-zone $2 \mathrm{~b}$, local and regional charcoal both display pronounced increases in abundance.
3.2.4. Pollen sub-zone 2c (282-216 cm: ca. 12,500 to ca. $10100 \mathrm{BP}$ )

A marked decrease in Isoëtes spore percentages (from 45 to $<25 \%$ ) and concentrations (from 12,000 to $\sim 5,000$ grains $/ \mathrm{cm}^{3}$ ), accompanied by a substantial increase in Cyperaceae pollen percentages (from 7 to $27 \%$ ) and concentrations (from 700 to 8,000 grains/ $\mathrm{cm}^{3}$ ), signals the transition from pollen sub-zone $2 \mathrm{~b}$ to sub-zone 2c. Total pollen concentration also increases substantially from the previous zone, peaking at $\sim 41,000$ grains $/ \mathrm{cm}^{3}$. Poaceae pollen percentages remain high (50-60\%). In this zone pollen percentages of puna taxa (e.g. Apiaceae, Brassicaceae, Iridaceae, Geraniaceae, Malvaceae, Ranunculaceae, and Valeriana) decrease. Pediastrum types 2 and 3 decrease in abundance, while type 1 Pediastrum increases markedly. Both size fractions of charcoal increase in abundance.

\subsubsection{Pollen sub-zone 2d (216-192 cm: ca. 10,100 to $c$. $7,950 \mathrm{BP}$ )}

In general, the transition from pollen sub-zone 2c to pollen sub-zone $2 \mathrm{~d}$ is characterized by an initial increase followed by a decrease in pollen percentages and concentrations of Cyperaceae. Polylepis/ Acaena pollen increases in importance throughout this zone, while Isoëtes spores continue to decline in abundance. Total pollen concentration ranges between 15,000 and 25,000 grains $/ \mathrm{cm}^{3}$. Poaceae pollen concentrations remain high. Other important taxa include Plantago, Asteraceae, and Moraceae/Urticaceae. All three forms of Pediastrum are rare. Local $(\geq 180 \mu \mathrm{m})$ charcoal abundance increases, while regional charcoal $(<180 \mu \mathrm{m})$ abundance remains relatively stable.

\subsubsection{Pollen zone 3 (192-68 cm: ca. 7,950 to ca. 3,100 BP)}

Maximal total pollen concentration $(85,000$ grains $\left./ \mathrm{cm}^{3}\right)$ and influx $\left(>2,000\right.$ grains $\left./ \mathrm{cm}^{2} / \mathrm{yr}\right)$ occur in zone 3 between 6,000 and 5,000 BP. High pollen percentages of Poaceae $(\leq 65 \%)$, Asteraceae

Figure 3. (Preceding page) Pollen concentration diagram for selected taxa found in sediments from Lake Titicaca, Peru/Bolivia. Unless otherwise noted all concentrations are $\times 10$ of axial value. Note variable scales. 


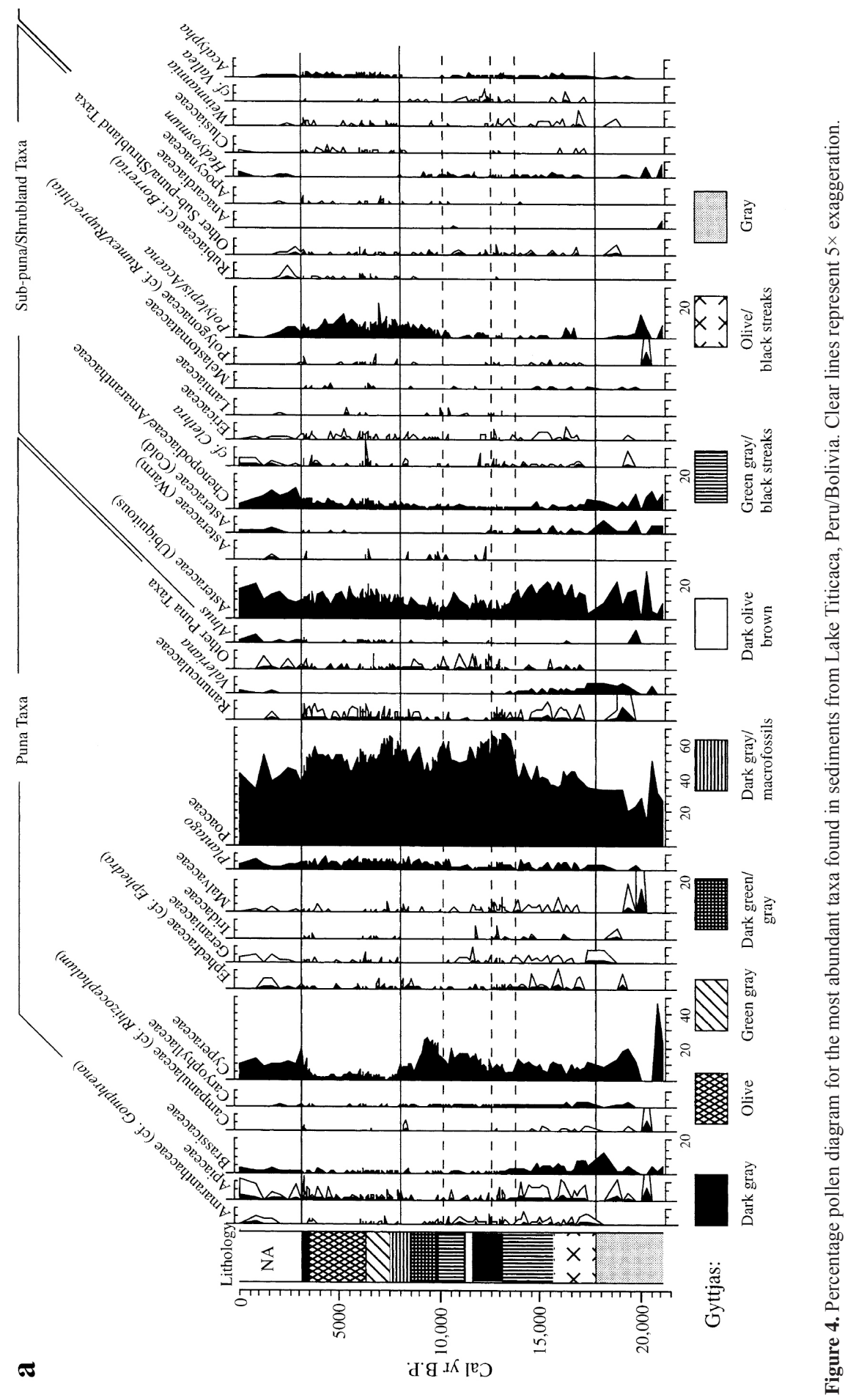




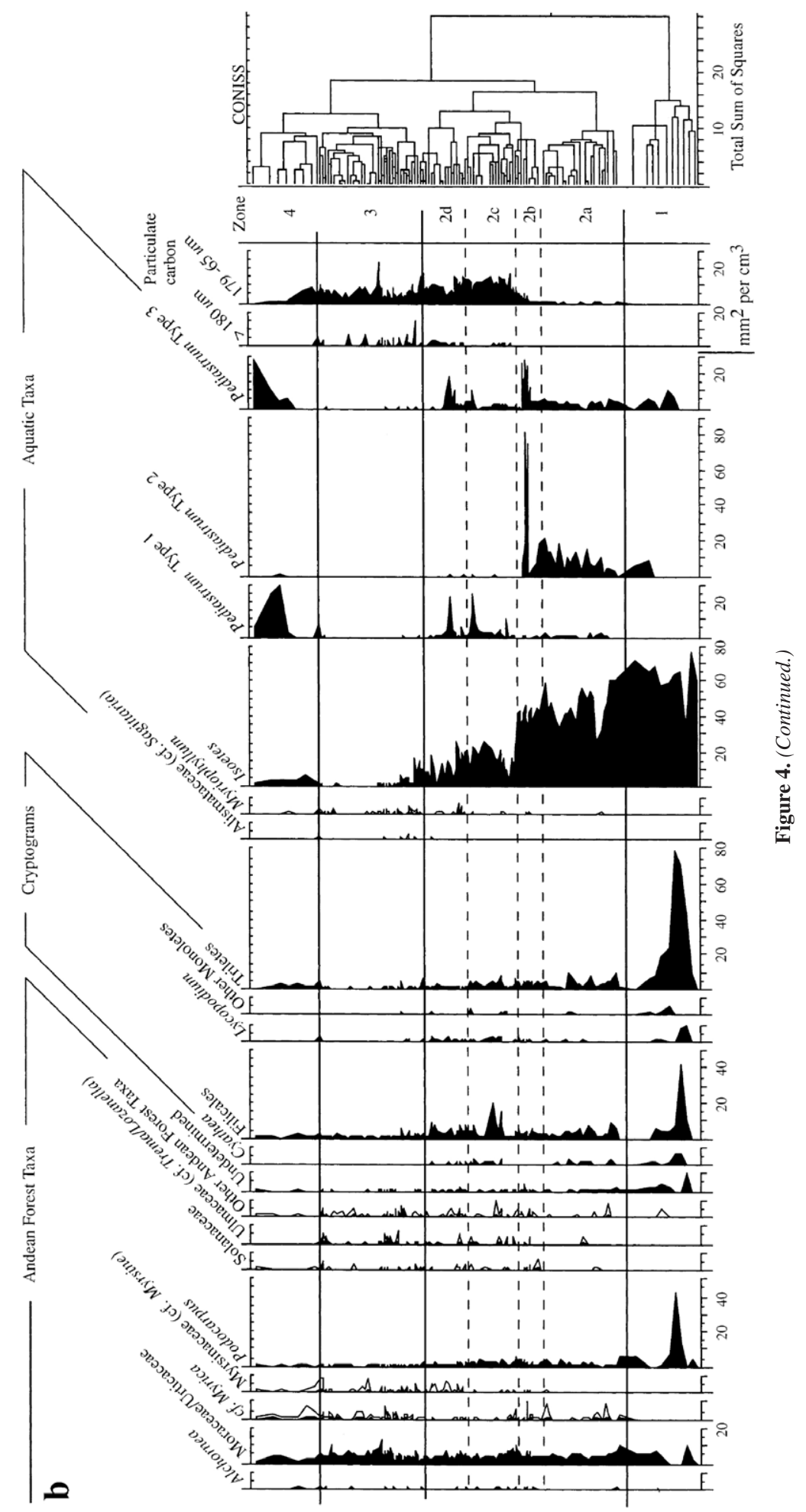




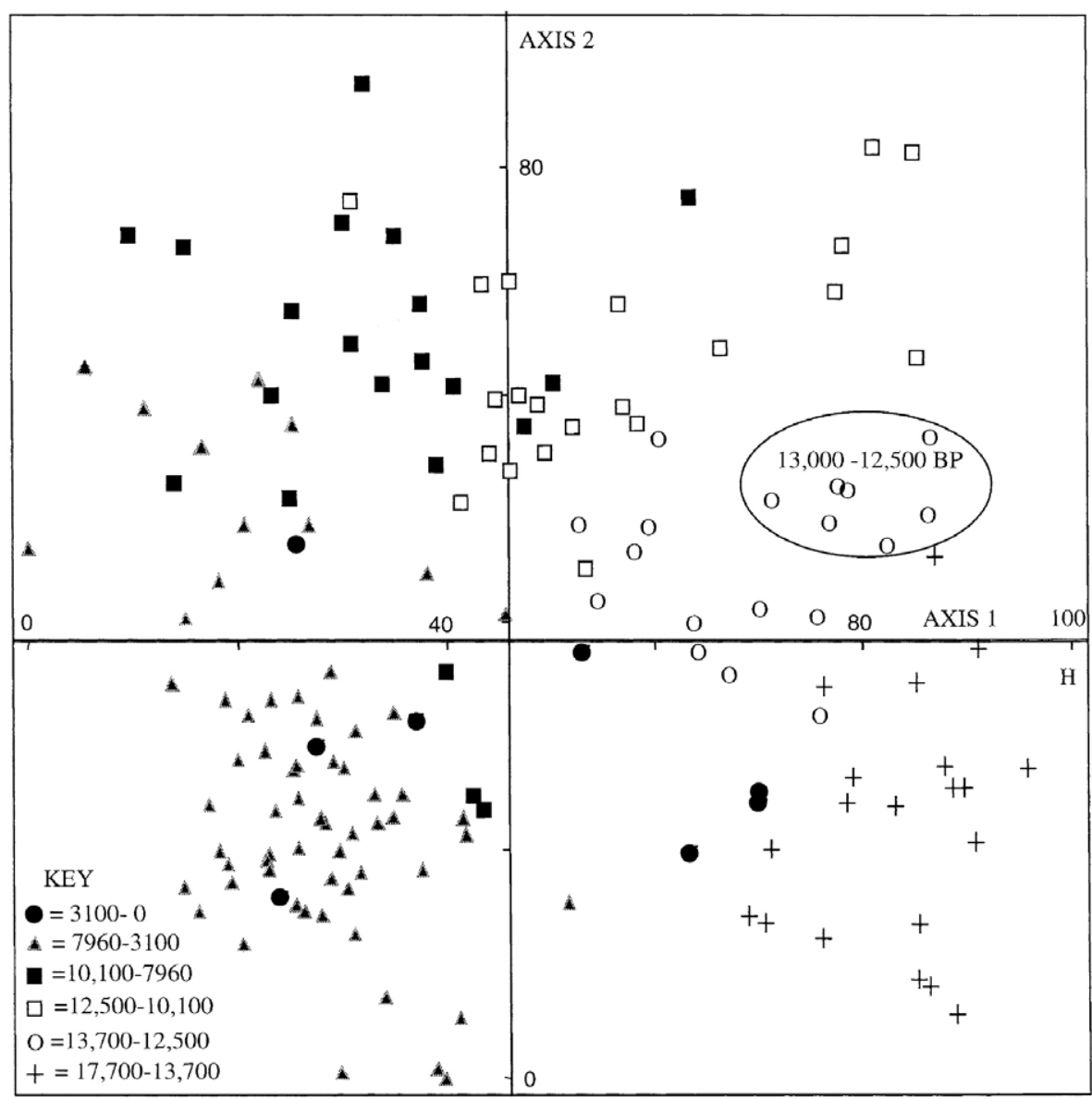

Figure 5. Results of the DCA of log-transformed percentile pollen data from Lake Titicaca, Peru/Bolivia. Analysis was restricted to terrestrial types occurring in five or more samples. Samples are divided according to zonation of pollen diagram. The circle encloses all the samples belonging to the event between 13,000 and $12,500 \mathrm{BP}$ that could represent a cooling, or response to fire. Only samples with at least 300 pollen grains were included in the analysis.

(20\%) and Polylepis/Acaena (20\%) characterize this zone. Cyperaceae exhibit a substantial decline in pollen percentage from the previous zone, contributing $5-10 \%$ of the total pollen sum. This decline corresponds to increased occurrences of Apiaceae, Ranunculaceae, Polylepis/Acaena, and Chenopodiaceae/ Amaranthaceae. Some Andean forest elements, e.g. Acalypha, Apocynaceae, Clusiaceae, and Moraceae/ Urticaceae, increase in importance, while Isoëtes spore percentages continued to decline (from 20\% to $<5 \%$ ) throughout zone 3 . Local and regional charcoal is abundant.
3.2.7. Pollen zone 4 (68 cm-Box $1 \mathrm{~cm}$ : ca. 3,100 BP to Present)

Decreased local and regional charcoal, increased Isoëtes spore percentages, and increased pollen percentages of Cyperaceae and Chenopodiaceae/Amaranthaceae characterize the transition between zones 3 and 4. Poaceae and Asteraceae remained the dominant taxa of zone 4 , contributing $\leq 55 \%$ and $\leq 20 \%$, respectively, to the pollen sum. Percentages of Apiaceae, Brassicaceae, Asteraceae (cold), Alnus, Hedyosmum, Valeriana, and Geraniaceae pollen increase. Polylepis/Acaena and Moraceae/Urticaceae pollen 
percentages decrease; and Plantago rises in abundance late in the zone. Total pollen concentration decreased from the previous zone and ranged between 5,000 and 24,000 grains $/ \mathrm{cm}^{3}$. Pediastrum types 1 and 3 re-appear in the record.

\subsection{Statistical analysis}

DCA was performed using log-transformed percentage data of terrestrial pollen taxa encountered in five or more sampled intervals. Samples in which 300 pollen grains were counted were included in the analysis (Figure 5 and Figure 6). In general, axis 1 separates Pleistocene from Holocene samples and is interpreted as an axis reflecting decreasing temperatures, while axis 2 is not clearly interpretable but provides a separation of early- from mid-Holocene samples.

\section{Discussion}

\subsection{Last Glacial Maximum}

Prior to ca. 21,500 BP, the area surrounding the Altiplano experienced extensive glaciation; Altiplano snowline was as low as $4,350 \mathrm{~m}$, about $500 \mathrm{~m}$ below present elevations (Seltzer, 1990). Very low pollen and spore concentrations $\left(\leq 2,000\right.$ grains $\left./ \mathrm{cm}^{3}\right)$ suggest that the glacial foreland was sparsely vegetated and that the lake did not support Isoëtes. The lack of pollen, spores, and the alga Pediastrum from the sedimentary record is consistent with a cooling of at least 5- $8^{\circ} \mathrm{C}$ (Ybert, 1988 and Ybert, 1992). A temperature depression of this magnitude during the LGM has previously been suggested from other South American records (Ashworth and Hoganson, 1993; Van der Hammen, 1974 and Wright et al., 1989).

Вy са. 21,000 BP spores of Isoëtes are the most abundant components of the palynological spectrum. Interpreting the Isoëtes record is clearly important, but it is not simple. Isoëtes can grow as a marginal plant, submerged to a depth of $4 \mathrm{~m}$ (Cleef, 1981), as an emergent at the margin of a lake, or in rivulets associated with eroding landscapes (P. Nuñez, personal communication). Isoëtes is sensitive to prolonged ice cover (Cleef, 1981) and consequently, its abundance could also reflect critical changes in temperature.

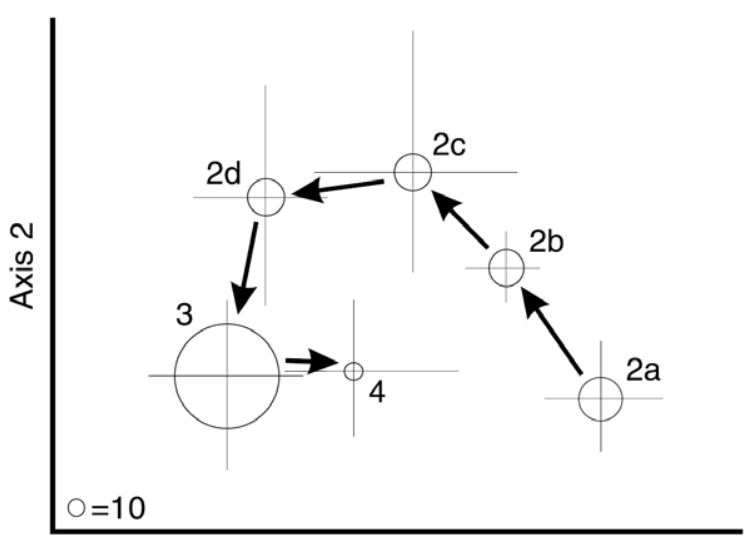

Axis 1

Figure 6. Summary diagram of DCA results of terrestrial pollen from Lake Titicaca, Peru/Bolivia. Numbers correspond to pollen zones. The size of the circle is proportional to the number of samples in each zone and the cross hairs represent the standard deviation of values from the mean position on axes 1 and 2. Arrows indicate the trend from oldest to youngest group.

Thus three different factors, lake level, erosion, and temperature, could all contribute to the Isoëtes signal.

Despite the fluctuations of lake level at Titicaca in the last 25,000 years (e.g. Baker et al., 2001b), the $150 \mathrm{~m}$ depth of the coring site precludes the presence of Isoëtes growing at that location. Thus the spores must have come from a shoreline at some distance from the coring site. Lake Titicaca lies in a steepsided basin, with few areas, including those presently submerged, where large populations of Isoëtes could occur. The most likely area that could have supported a substantial population of Isoëtes is the littoral marshes, that lie just above present lake level, west of the coring site. If these marshes were permanently flooded, Isoëtes could become a prominent component of the palynological spectrum.

The second, compatible scenario is that in a landscape with sparse vegetation and erratic rainfall, or an increasing volume of meltwater, gulleying may have been widespread. Small streams flowing in the gulleys could have provided further habitat for Isoëtes.

A third and not mutually exclusive explanation of increased Isoëtes representation is a simple warming. Isoëtes does not grow in water that freezes (Cleef, 1981), and so thawing of the margins of Titicaca 
could explain the rapid appearance of Isoëtes in the record. Shortly after Isoëtes increases in abundance, high percentages of the open-water alga Pediastrum occur. Modern studies indicate that Pediastrum is absent from high-altitude lakes in the Hichu Kkota valley east of Lake Titicaca, suggesting that it is temperature-sensitive (Ybert, 1992). The sequential rise of Isoëtes and Pediastrum may suggest the onset of warming took place as early as $21,000 \mathrm{BP}$ at Titicaca.

All of these scenarios would probably increase lake volume. Thus the data are consistent with Baker et al.'s (2001b) assertion that water level after ca. 21,000 BP was higher than present. According to the palynological evidence these conditions were maintained until ca. 17,700 BP.

A recent sea-surface temperature reconstruction (Hostetler and Mix, 1999 and Mix et al., 1999) suggests a $\sim 5^{\circ} \mathrm{C}$ cooling of the equatorial Pacific during the LGM. Extending westward from Peru along the Equator, this cooling produced a cold tongue similar to "a perpetual La Niña climate state" (Hostetler and Mix, 1999). As La Niña years correlate with enhanced precipitation on the Altiplano (Roche et al., 1992), the increased water levels inferred from the Titicaca record are consistent with model predictions. These data are also consistent with the chronology of a paleolake Tauca highstand in the central Altiplano, initiated prior to deglaciation (Baker et al., 2001a).

\subsection{Deglaciation}

The initial increase in Isoëtes at 21,000 BP may indicate the earliest shift to warmer conditions, as indicated by geochemical data (Seltzer et al., 2002). Certainly, increased pollen concentrations after ca. $17,700 \mathrm{BP}$ suggest the development of a dense vegetation cover. These samples, the oldest used in the statistical analysis, lie at the positive extreme of axis 1 (Figure 5) of the ordination results. Puna brava vegetation is suggested by pollen concentrations of $<5,000$ grains $/ \mathrm{cm}^{3}$, and high percentages of Poaceae (35-48\%), Cyperaceae (15\%), Brassicaceae (12\%), Valeriana (8\%), Caryophyllaceae (5\%) and Plantago (5\%). During this late glacial period, relatively high percentages (5-10\%) of Moraceae/ Urticaceae and Podocarpus are attributed to longdistance transport of pollen from lower-elevation vegetated areas (Hansen et al., 1984 and Markgraf, 1980), a common phenomenon in areas of low local pollen production. The climate was still very cold. The continued presence of high inputs of Isoëtes is consistent with stabilized rivulet and littoral habitats. We attribute low local and regional charcoal abundance to a low fuel load rather than climatic factors. High pollen percentages of marsh taxa (e.g. Apiaceae, Cyperaceae, Plantago, Polygonaceae) suggest a well-developed littoral fringe. Combined with high spore percentages of Isoëtes (60-65\%), these two factors suggest higher water levels during this period.

Increased pollen concentrations and pollen percentages of puna and sub-puna vegetation including Asteraceae, Gomphrena, Ephedra, Ericaceae, Geraniaceae, Malvaceae and Ranunculaceae suggest transition from puna brava to puna environment after ca. $17,000 \mathrm{BP}$. The vegetation suggests that temperatures rose to ca. $2-3^{\circ} \mathrm{C}$ below present. This interpretation is consistent with previous research documenting widespread deglaciation throughout the tropical Andes between ca. 18,000 and ca. 16,000 BP (e.g. Seltzer et al., 2000).

Between ca. 17,000 BP and ca. 12,500 BP, oscillations between Cyperaceae pollen and Isoëtes spores in the palynological profile reflect marked water level fluctuations on the Altiplano. As Titicaca dropped below overflow level ca. 15,000 BP (Baker et al., 2001b), the community composition of the littoral marshes began to change. We suggest that declining inflow, as a result of less meltwater or less precipitation, caused a fall in lake level. As the western littoral marshes became drier and flow in surface channels was reduced, Cyperaceae replaced Isoëtes in the palynological record. Periodically, this overall pattern was interrupted by short periods of enhanced precipitation in which Isoëtes populations rebounded at the expense of Cyperaceae.

By tracking changes in Poaceae size frequency, it is possible to determine when substantial shifts in Poaceae community composition occur. The pollen size of each species of Poaceae has an approxi- 
mately normal size distribution (Beug, 1961 and Salgado-Labouriau and Rinaldi, 1990). Consequently, a given community of grasses should have a characteristic polynomial size distribution (Bush, 1986). In the Titicaca record, Poaceae pollen size class data show continual variation, but some patterns are evident (Figure 7). Between ca. 17,000 and 15,000 BP very large grass pollen $(>40 \mu \mathrm{m})$ is evident in all samples. Between ca. 12,500 BP and 8,500 BP these very large Poaceae pollen and the smallest Poaceae grains $(<18 \mu \mathrm{m})$ are absent from the record. These changes in size spectra could be due to climatic change, but they may also be linked to the presence of fire. As deglaciation proceeded, and local productivity increased, the slopes around Titicaca supported enough grasses, herbs and woody taxa, e.g. Polylepis, to carry fire. Because fire does not burn entire landscapes, such as the catchment of Titicaca, evenly or simultaneously, some lag between the first evidence of fire and an effect on total pollen signature is anticipated. Small amounts of charcoal are evident from 17,700 BP, but the first consistent representation in quantities sufficient to suggest fires within the Titicaca catchment occur at ca. 13,200 BP. The marked change in Poaceae abundance at 13,700 BP coincides with some changes in size frequency toward the $31-40-\mu \mathrm{m}$ classes and a corresponding reduction in the 19-24- $\mu \mathrm{m}$ classes. As the change in
Poaceae abundance precedes the rise of charcoal it is inferred that fire was not causal, though it was undoubtedly a significant force upon local vegetation after ca. 13,200 BP.

Van Geel and Van der Hammen (1973) dated the Guantiva Interstadial in the Sabana de Bogotá, Colombia to between ca. 14,700 BP and ca. 13,000 BP. This well-documented warm, wet event (Helmens and Kuhry, 1986 and Van der Hammen, 1974) is considered to be an equivalent to the European Allerød Interstadial (Van der Hammen and Hooghiemstra, 1995). Other South American records also indicate interstadial conditions during this period (e.g. Salgado-Labouriau et al., 1977 and Thompson et al., 1998). However, large changes in pollen percentages and concentrations of most taxa are not evident from the Lake Titicaca sedimentary sequence prior to ca. 13,700 BP. Decreased Cyperaceae pollen and Isoëtes spore concentrations may indicate contraction of marginal wetlands as moisture levels fluctuated. If an interstadial event contemporaneous with the Guantiva of Colombia was experienced on the Altiplano, it did not cause vegetation shifts in the surrounding area. The late glacial (17,700-13,000 BP) at Titicaca pollen record, however, is consistent with reduced, not increased moisture levels during this period (e.g. Sylvestre et al., 1999; Wirrmann et al., 1992 and Ybert, 1992).

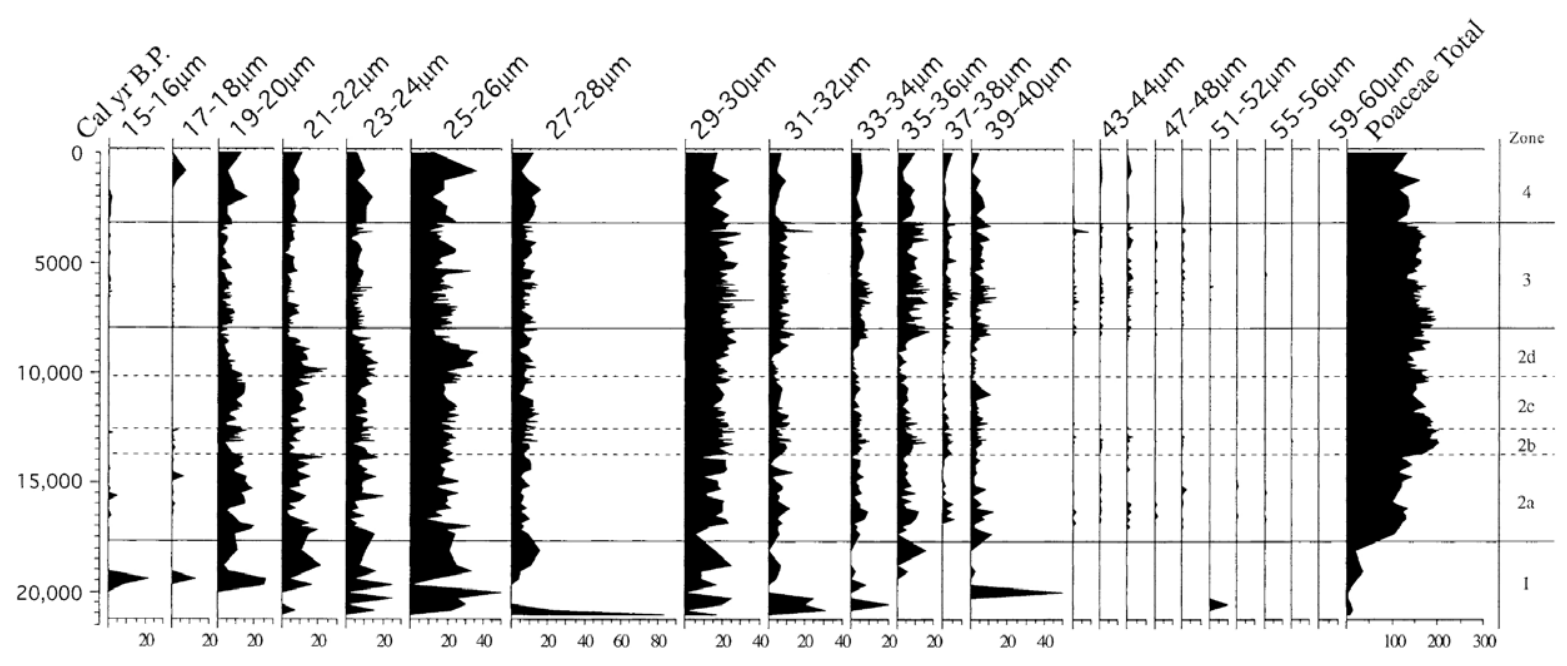

Figure 7. Percentage occurrence of Poaceae pollen in 2- $\mu \mathrm{m}$ size classes from Lake Titicaca, Peru/Bolivia. 


\subsection{Is a Younger Dryas-style event evident at Lake} Titicaca?

No clear evidence exists to support the abrupt cooling and subsequent warming that typifies the Younger Dryas event in Europe. At Titicaca, a unidirectional climatic warming took place between ca. 21,000 BP and 13,000 BP. Between 13,000 BP and 12,500 BP samples are clustered by the DCA and appear as a group somewhat isolated from neighboring samples, lying closer to the bulk of late glacial samples than the samples immediately downcore. While this could indicate a climatic reversal to cool conditions, if it occurred it was subtle, exerting little influence on the vegetation. Asteraceae (cold type) have their final expansion between 13,000 BP and 12,500 BP period, but there is little else to indicate cooling. The interpretation of this event is further complicated by it coinciding with the onset of regular fires in the catchment. Consequently, it may be more parsimonious to interpret the period between 13,000 and $12,500 \mathrm{BP}$ as a period in which vegetation adjusted to fire, rather than to assert the presence of a climatic reversal.

After ca. 12,500 BP, a gradual warming continued until the early Holocene (ca. 10,000 BP), as concentrations of puna brava taxa, e.g. Geraniaceae, Malvaceae, Ranunculaceae, Valeriana, decreased while concentrations of sub-puna shrubland, e.g. Alnus, Polylepis/Acaena, and Andean forest elements increased.

Falling lake levels after ca. 12,500 BP are indicated by a substantial decrease in Isoëtes spore concentrations, and low inputs of cryptogams. Cyperaceae and Apiaceae replaced Isoëtes, probably resulting from a falling hydrology in the western littoral marshes. Concomitant increases in Caryophyllaceae and Ephedra concentrations also argue for lower moisture levels, as does a spike in benthic diatoms about 11,500 BP (Baker et al., 2001b).

\subsection{Pleistocene/Holocene transition}

The Pleistocene/Holocene transition at Titicaca is progressive and does not have a distinct onset as identifiable as that of some other Andean records (e.g. Thompson et al., 1998 and Hansen et al.,
1994). From other records this transition would be expected around 11,000 BP (Colinvaux et al., 1997 and Rodbell, 1993), and the best evidence of a significant change at that age in the Titicaca record is an increase in pollen concentration. However, from ca. $17,700 \mathrm{BP}$ there is a steady reduction in pollen of puna brava taxa (e.g. Brassicaceae, Geraniaceae, Malvaceae, and Valeriana) as temperatures increased. The steady decline in Isoëtes throughout this period reflects a combination of increasing temperatures, increased competition from angiosperms, and decreasing marsh extent. Although some range adjustment of species continued into the Holocene, the major shifts in vegetation types attributable to warming appear to have taken place by about 13,700 BP.

Between ca. 12,500 BP and 11,500 BP a sharp decline in Isoëtes and a brief peak of Polylepis and matching losses of Filicales and Triletes coincide with the first consistent occurrence of large charcoal particles. Polylepis is not normally associated with dry conditions (Graf, 1981), but its occurrence in this record may reflect hydrarch succession on the marshes. These areas would still be mesic compared with most habitats, but no longer support dense stands of Isoëtes or Cyperaceae. The combination of this pattern and the observation that this pattern recurs in the mid-Holocene during a time that is well documented as a lowstand suggests that the 12,500 to $11,500 \mathrm{BP}$ event is a time of low lake level.

Lake level probably rose between 11,500 and ca. 9,000 BP, an observation consistent with diatom and isotopic data which suggest that between 10,000 and 8,500 BP the lake deepened, spilling over the sill (currently about $6 \mathrm{~m}$ above normal lake level) into the Rio Desaguadero (Baker et al., 2001b). Despite relatively high lake level Isoëtes is losing habitat as Cyperaceae expands. Cyperaceae (including the great Tortora beds and floating islands) are competing for the area occupied by Isoëtes and probably had a competitive advantage as the climate warmed. Polylepis also expands in abundance during this wet phase. The western marshes are flooded during this phase, but the additional moisture provided suitable habitat for Polylepis expansion on the surrounding slopes. 


\subsection{A Mid-Holocene dry event}

A decline in Isoëtes spores and Cyperaceae pollen and increase in large charcoal abundance begins at 9,000 BP, suggesting that the climate is becoming drier and that lake level is falling. Between ca. 7,960 BP and ca. 3,100 BP a distinct lowstand is evident in which Cyperaceae is largely replaced by Poaceae and Polylepis, and local fires are periodic but regular features of the landscape. The large charcoal fraction provides an unusually spiky record during this period. The run of data is too short to demonstrate cyclicity, but it appears that fire frequency, and by inference drought, was not constant throughout this period. The DCA results group samples from this dry event toward the negative extremes of both axes 1 and 2. Paleobiotic and geochemical data (Baker et al., 2001b) indicate that water level had declined as much as $100 \mathrm{~m}$ in the Lago Grande basin, reaching its lowest level ca. 6,000-5,000 BP (Cross et al., 2001 and Seltzer et al., 1998). This lowstand coincides with the zone of highest pollen influx (approximately double any other section of the core). The higher pollen influx probably reflects a closer pollen source as the lake contracted. These findings are entirely consistent with previous reports of a dry mid-Holocene at Titicaca (Baker et al., 2001b; Cross et al., 2001 and Seltzer et al., 1998).

As the water body contracted and conditions became more saline (Cross et al., 2001), aquatic and marginal vegetation changed in composition. Pediastrum and Sagittaria are lost from the record relatively early, between ca. 7,000 and 3,100 BP, while the submerged aquatic macrophyte Myriophyllum declines steadily in abundance, disappearing from the record between ca. 6,000 and 4,000 BP. In the adjacent marshes Chenopodiaceae/Amaranthaceae replaced Cyperaceae, a response consistent with the inferred changes in ionic concentrations. The strong evidence of local climatic change and a lack of archeological evidence of human occupation until the late Holocene support the interpretation of local fire frequency as a further indication of climatic change rather than extensive human disturbance.
Throughout this period (ca. 8,000 to ca. 3,100 $\mathrm{BP})$ pollen concentrations are higher than during any other zone. Contributory factors to this pattern could be closer pollen sources as lake extent contracts, a reduction in sediment accumulation rate, or increased temperatures permitting expansion of Andean forest taxa and thus a closer proximity of the treeline to the deposition site.

The pronounced increase in Polylepis/Acaena pollen is consistent with closer source area as Polylepis invades the fertile muds exposed by falling lake level. A mid-Holocene thermal optimum is also possible as montane forest taxa, e.g. Acalypha, Clethraceae, Clusiaceae, Myrica, Myrsine, Moraceae/Urticaceae, and Weinmannia, increase in abundance, consistent with an upslope migration of taxa.

If modern treelines are in equilibrium with modern climate, an upslope shift of vegetation by 200 $600 \mathrm{~m}$ during the mid-Holocene suggests that conditions were $1-3^{\circ} \mathrm{C}$ warmer than today (but see below). Palynological evidence from northern Bolivia (Graf, 1981) and ice core evidence from Peru (Thompson et al., 1995) support this interpretation. However, the Lago Wiñaymarka sedimentary sequence is interpreted to indicate slightly cooler conditions between ca. 8,700 and ca. 6,500 BP, and $1-2^{\circ} \mathrm{C}$ cooler at 5,800 BP (Ybert, 1992). It is not clear, however, which line(s) of evidence support these interpretations. Furthermore, no radiocarbon dates were available to support this chronology.

The mid-Holocene dry period appears to fade between 4,000 BP and 3,100 BP, as pollen concentrations of moist elements (e.g. Apiaceae, Alnus, Acalypha, Hedyosmum) increased, and Myriophyllum returns to the record. After ca. 3,700 BP, increased pollen percentages of Cyperaceae signal flooding of the western littoral marshes as lake level rose (e.g. Abbott et al., 1997b and Wirmann et al., 1988). By ca. 3,300 BP, precipitation had increased sufficiently to support an expanded population of Isoëtes along the western lake boundary.

\subsection{Anthropogenic effects}

Human modification of Andean environments is evident throughout the Holocene, and the Altiplano 
has a long history of occupation (Aldenderfer, 1998 and Klink and Aldenderfer, 1996). Cultivated plants first appeared around 10,000 BP in South America (Piperno and Stothert, 2003), but agriculture was not widespread in the Altiplano prior to ca. 3,400 BP (Binford et al., 1996).

In the Titicaca pollen record no clear evidence of agriculture was found in the mid-Holocene. The increase in Chenopodiaceae/Amaranthaceae at ca. 7,300 BP could reflect early agriculture, but we suggest that given all other indicators, a climatic explanation is more parsimonious. After ca. 4,000 BP decreased abundances of local and regional charcoal suggest a reduction in fire frequency. Although a climatic explanation may lie in heightened ENSO variability (Rodbell et al., 1999; Rowe et al., 2002 and Sandweiss et al., 1996), resulting in enhanced moisture levels on the Altiplano, human activity may also be important in reduced fire frequency. Large-scale agricultural practices on the Altiplano commenced ca. 3,600 BP to ca. 3,200 BP, with riparian populations approaching maximum densities between ca. 2,000 BP and ca. 1,450 BP (Binford et al., 1996). Overexploitation of firewood resources leading to a general loss of forest cover has been documented in other tropical regions (Binford et al., 1997 and Bush et al., 1992). Fine particulate charcoal concentrations increase between 4,000 and 2,600 BP but decline and ultimately disappear from the record after 2,000 BP. This pattern is consistent with intensifying land use leading to a progressive loss of forest cover and eventual lack of fuelwood.

This projected loss of firewood is reflected in the pollen record. After ca. 3,100 BP arboreal species decline in abundance and open-ground weed species reflecting disturbed soils become more abundant. Some puna families, such as Valerianaceae, Apiaceae, Geraniaceae, Caryophyllaceae and Brassicaceae, can be classic weed species of field margins and grazed grasslands. Agriculture and grazing reduces ground cover and increases soil disturbance, factors that favor the spread of these families into sub-puna habitats.

Multivariate analysis suggests that these late Holocene samples (i.e. after ca. 3,100 BP) are highly diverse with a wide range of affinities. Some of the samples lie close to the mid-Holocene dry-spell samples, while others show a stronger similarity to Pleistocene samples (Figure 5). Such shifts in the upper portion of ordination in which modern and Pleistocene samples plot close to one another are quite common (e.g. Bush, 1993 and Bush et al., 1992). Either these data suggest very rapid and profound climate change, or the activities of humans are creating an environment similar in its openness to that of the Pleistocene.

Human activities in the sub-puna can replicate the mosaic of bare ground and herbaceous vegetation that characterized deglacial landscapes. Much of the modern treeless sub-puna of Peru is below the potential treeline and is maintained as open grazing land by land management (Ellenberg, 1975). It is probable that the apparent mid-Holocene expansion of Andean taxa reflected an upslope migration in response to climate change. However, the subsequent loss of those taxa is not wholly attributable to late Holocene cooling but to deforestation. Consequently, assuming that modern treelines are in equilibrium with modern temperatures leads to an underestimation of glacialage cooling and an overestimation of mid-Holocene warming. The statistical analysis (Figure 6) has faithfully reproduced a shift to more open conditions, but the cause of this shift is not a climatic reversal, but the presence of human disturbance.

A shift in Poaceae size class distribution also occurred at 3,100 BP, signaling a change in community composition (Figure 7). Grains $\leq 24 \mu \mathrm{m}$ increased in importance as some larger grains decreased in representation. This change in community composition may reflect the return of open-ground taxa, or alternatively grasses tolerant of cropping by grazers such as alpaca and vicuña.

Chenopodiaceae/Amaranthaceae reach a maximal pollen percentage (14\%) after ca. 2,600 BP. The increase may reflect changing environmental conditions (i.e. disturbance, saline conditions), however, the increase is more likely the result of anthropogenic factors. The pollen of these families could represent weeds associated with disturbed ground, or be derived from cultivars. Three of the major cultivars of the Tiwanaku civilization, Amaranthus caudatus, Chenopodium quinoa, and Che- 
nopodium palidicaule (Binford et al., 1996) are included within the Chenopodiaceae/Amaranthaceae, and their pollen are morphologically indistinct from naturally occurring members. A further indicator of human disturbance may be the increase in Pediastrum abundance in the last 2,000 years. Increased algal populations may reflect eutrophication of the lake as a result of soil erosion contributing nutrients to the lake.

\subsection{A lack of uniformity}

The Titicaca record of lake level change is broadly dissimilar to that of the Sabana de Bogotá, Colombia. At the LGM, lake level in the Sabana de Bogotá was relatively low, whereas Titicaca was high (Baker et al., 2001a; Baker et al., 2001b and Hooghiemstra, 1984). Northern versus southern tropical lakes had opposing signatures of lake level at a variety of temporal scales (Bradbury et al., 2001 and Fritz et al., 2001), thus it is not surprising to find the contrasting histories of Titicaca and the Sabana de Bogotá. It is more surprising to find strong regional variation in climatic history between records from the Altiplano and the Atacama.

The interpretation of dry conditions during the mid-Holocene at Titicaca is consistent with palynological, sedimentological, and glacial evidence from other regions of Bolivia, Peru, and the Atacama Altiplano (e.g. Abbott et al., 1997a; Binford et al., 1996 and Hansen et al., 1994), but forms a striking contrast with recent investigations from Chile (Betancourt et al., 2000 and Holmgren et al., 2001). Betancourt et al. (2000) examined fossil rodent middens and wetland deposits to reconstruct paleoprecipitation levels in the central Atacama desert. From these data, the period between ca. 8,000 and ca. 3,000 BP was interpreted as a wet phase.

Although lying in different catchments and therefore entirely capable of having different hydrologic histories, synoptic climatic events of sufficient scale to draw Titicaca down $100 \mathrm{~m}$ yet cause the Atacama desert to bloom (Betancourt et al., 2000) are intriguing. No overarching explanation for these disparate events has been advanced, but some of the apparent discrepancy may be explained by the possibility that the midden and wetland data may document explicit events that are invisible in the Titicaca record. Rodent middens are probably discontinuous, and a single midden may represent many phases of colonization and abandonment. The middens, therefore, may offer a high-resolution sequence of "snapshots" of local vegetation at discrete intervals. With increased precipitation, forage increases and populations of rodents flourish. Hence the phases of accumulation will be greater under conditions of normal or greater than normal rainfall. However, any prolonged period of severe drought is likely to lead to abandonment and no accumulation. Hence the middens inevitably provide a record that documents 'wetter-than-normal' events, but few if any records of drought. In contrast, the continuous but temporally and spatially buffered record from Lake Titicaca offers a more general reconstruction of climatic conditions during the midHolocene. Perhaps the message that can be drawn from merging the Atacama and Altiplano observations is that the mid-Holocene climates were not uniformly dry, but within an overall pattern of reduced precipitation the wet events provided climatic heterogeneity more apparent at smaller spatial and temporal scales. Indeed the diatom record from Lake Titicaca shows a resurgence of lake level from 7,000 to 6,000 BP within the overall aridity of the mid-Holocene (Baker et al., 2001b).

However, such an explanation does not account for evidence that the period post ca. 3,000 BP was one of the driest periods in the last 22,000 years in the Atacama, while it was moist on the Altiplano (Baker et al., 2001a; Baker et al., 2001b and Betancourt et al., 2000). Undoubtedly expecting precipitation systems to be uniform across large areas where prevailing winds and topography provide strong habitat heterogeneity is unrealistic. Until data for an individual site fit within a robust model of paleoclimatic change, it is dangerous to extrapolate to other areas. This limitation is especially true in very dry environments, where small differences in precipitation can trigger large ecological changes, and where inter-annual precipitation variability is large. 


\section{Conclusions}

Pollen and charcoal analysis of two cores from Lake Titicaca at high temporal resolution reveal significant changes in vegetation composition and plant distributions on the Altiplano over the past ca. 27,500 years. Prior to ca. 21,500 BP, pollen concentrations were very low, plant cover was intermittent, and lake level was high. The absence of local pollen production is consistent with sufficient cooling to drive puna brava vegetation below the elevation of Titicaca. The inferred change in vegetation is ca. 1,000-1,300 $\mathrm{m}$ in elevation, consistent with a cooling of $5^{\circ} \mathrm{C}$ relative to modern temperatures. The very cold climatic conditions prevailed until ca. 21,000 BP, when the appearance of Isoëtes and the alga Pediastrum signaled an initial climatic warming. Increased pollen concentrations after ca. 17,700 BP suggest the rapid development of a dense vegetation cover comprised of puna and puna brava elements. The response of vegetation on the glacial forelands to warming appears to precede the retreat of local glaciers (Rodbell and Seltzer, 2000). The replacement of puna brava vegetation by puna taxa coincides with estimates of glacial retreat at ca. 16,850 BP. Temperatures are inferred to have risen to within $2-3^{\circ} \mathrm{C}$ of the present at this time.

Fire was not a regular feature of the Altiplano at the LGM due to a lack of fuel. After ca. 17,700 BP, as denser vegetation became established, fine particulate charcoal is evident in the sedimentary record. A marked increase in consistency of the occurrence of charcoal is evident at ca. 14,500 BP, and is followed by an increase in abundance at $13,700 \mathrm{BP}$. The trajectory of increasing fire activity probably parallels increases in fuel load in the landscape around Titicaca. The occurrence of fire as early as $17,700 \mathrm{BP}$ and its regular occurrence by $13,700 \mathrm{BP}$ generally predates most estimates of human entry into South America (e.g. Fiedel, 1987) and argues strongly that fire is a natural component of Altiplano ecology.

The warming transition from Pleistocene to Holocene climates appears to have been gradual starting around 17,700 BP possibly continuing until ca. 6,000 BP. Although there is evidence of wetter and drier phases with the deglaciation, there is no evidence to support a distinct climatic event equivalent to the Guantiva Interstadial at 14,250 BP to ca. 13,500 (Van
Geel and Van der Hammen, 1973) or the Younger Dryas at 12,500-11,000 BP (Thompson et al., 1998). Indeed, the smooth transition out of Pleistocene conditions led to the establishment of near-modern communities around Titicaca as early as 13,700 BP. We do not assert that there was no Younger Dryas event at Titicaca, simply that no evidence exists to support such an argument based on the pollen record from Titicaca.

The most striking Holocene interval recorded in the Titicaca sequence was a dry phase centered between ca. 7,960 BP and 3,100 BP. Sharp decreases in pollen concentrations of Cyperaceae and Isoëtes suggest drying of the western littoral marshes. Concomitant increases in Chenopodiaceae/Amaranthaceae pollen suggest saline conditions as water level continued to drop. Fire became an important component of the landscape, as ample woody biomass provided fuel for burning. Decreased moisture levels related to changes in seasonality and insolation may be responsible. The peak of pollen concentration and of fire frequency at ca. 5,500 BP coincides with the estimate of lowest lake level (Baker et al., 2001b).

Pollen and charcoal evidence points to human-induced landscape change as early as 4,000 BP. Land use appears to peak when Chenopodiaceae/Amaranthaceae pollen and charcoal abundance reach peak abundances at ca. 2,600 BP. Thereafter, a comprehensive deforestation of the catchment is inferred from a progressive decline in charcoal abundance and the lack of arboreal pollen despite higher lake levels (Abbott et al., 1997a).

The Titicaca record demonstrates that the vegetation around high-elevation sites is a sensitive proxy of Quaternary climate change. With more information regarding the ecological tolerances and requirements of common plants represented by pollen and spores found in these deposits, even more information could be extracted from these records.

\section{Acknowledgements}

Funding for this analysis was provided by National Science Foundation Grant ATM 9906107. We are grateful to V. Markgraf, H.E. Wright, and an anonymous reviewer for insightful comments that improved the manuscript. 


\section{References}

Abbott, M.B., Binford, M.W., Brenner, M. and Kelts, K., 1997. A $3500{ }^{14} \mathrm{C}$ high-resolution record of water-level changes in Lake Titicaca, Bolivia/Peru. Quat. Res. 47, pp. 169-180.

Abbott, M.B., Seltzer, G.O., Kelts, K.R. and Southon, J., 1997. Holocene paleohydrology of the tropical Andes from lake records. Quat. Res. 47, pp. 70-80.

Aldenderfer, M., 1998. Montane Foragers: Asana and the South-Central Andean Archaic. University of Iowa Press, Iowa City, IA, 344 pp.

Ashworth, A.C. and Hoganson, J.W., 1993. The magnitude and rapidity of the climate change marking the end of the Pleistocene in the mid-latitudes of South America. Palaeogeogr. Palaeoclimatol. Palaeoecol. 101, pp. 263-270.

Baker, P.A., Rigsby, C.A., Seltzer, G.O., Fritz, S.C., Lowenstein, T.K., Bacher, N.P. and Veliz, C., 2001. Tropical climate changes at millennial and orbital timescales on the Bolivian Altiplano. Nature 409, pp. 698-701.

Baker, P.A., Seltzer, G.O., Fritz, S.C., Dunbar, R.B., Grove, M.J., Tapia, P.M., Cross, S.L., Rowe, H.D. and Broda, J.P., 2001. The history of South American tropical precipitation for the past 25,000 years. Science 291, pp. 640-643.

Bard, E., 1998. Geochemical and geophysical implications of the radiocarbon calibration. Geochim. Cosmochim. Acta 62, pp. 2025-2038.

Betancourt, J.L., Latorre, C., Rech, J.A., Quade, J. and Rylander, K.A., 2000. A 22,000-year record of monsoonal precipitation from northern Chile's Atacama Desert. Science 289, pp. 1542-1546.

Beug, H.G., 1961. Leitfaden der Pollenbestimmung für Mitteleuropa und Angrenzende Gebiete. Gustav Fischer Verlag, Stuttgart, 63 pp.

Binford, M.W., Brenner, M., Leyden, B.W., 1996. Paleolimnology and Tiwanaku agroecosystems. In: Kolata, A.L. (Ed.), Tiwanaku and its Hinterland: Archeological and Paleoecological Investigations of an Andean Civilization. Smithsonian Institution Press, Washington, DC, pp. 89-108.

Binford, M.W., Kolata, A.L., Brenner, M., Janusek, J., Seddon, M.T., Abbott, M.B. and Curtis, J.H., 1997. Climate variation and the rise and fall of an Andean civilization. Quat. Res. 47, pp. 235-248.

Boulange, B. and Aquize Jaen, J.E., 1981. Morphologie, hydrographie et climatologie du lac Titicaca et de son bassin versant. Rev. Hydrobiol. Trop. 14, pp. 269-287.

Bradbury, J.P., Grosjean, M., Stine, S., Sylvestre, F., 2001. Full and late glacial lake records along the PEP1 transect: Their role in developing interhemispheric paleoclimate interactions. In: Markgraf, V. (Ed.), Interhemi- spheric Climate Linkages. Academic Press, San Diego, CA, pp. 265-291.

Bush, M.B., 1986. The Late Quaternary History of the Great Wold Valley, East Yorkshire. Ph.D. Thesis, University of Hull, Hull.

Bush, M.B., 1993. An 11,400 yr paleoecological history of the British chalk grasslands. J. Veg. Sci. 4, pp. 47-66.

Bush, M.B., Piperno, D.R., Colinvaux, P.A., Krissek, L., De Oliveira, P.E., Miller, M.C. and Rowe, W., 1992. A 14,300 year paleoecological profile of a lowland tropical lake in Panama. Ecol. Monogr. 62, pp. 251-276.

Carmouze, J.P. and Aquize Jaen, E., 1981. La régulation hydrique du lac Titicaca et l'hydrologie de ses tributaires. Rev. Hydrobiol. Trop. 14, pp. 311-328.

Cerveny, R., 1999. Present climates of South America. In: Hobbs, J.E., Lindesay, J.A., Bidgman, H.A. (Eds.), Climates of the Southern Continents. John Wiley and Sons, Chichester, pp. 107-135.

Clapperton, C.W., 1993. Quaternary Geology and Geomorphology of South America. Elsevier, Amsterdam, 796 pp.

Clark, J.S., Patterson, W.A.I., 1997. Background and local charcoal in sediments: Scales of fire evidence in the paleorecord. In: Clark, J.S., Cachier, H., Goldammer, J.G., Stocks, B. (Eds.), Sediment Records of Biomass Burning and Global Change. NATO ASI Series, 1: Global Environmental Change, vol. 51. Springer, Berlin, pp. 23-48.

Cleef, A.M., 1981. The Vegetation of the Paramos of the Colombian Cordillera Oriental. Dissertationes Botanicae, University of Amsterdam, Amsterdam.

Colinvaux, P.A., Bush, M.B., Steinitz-Kannan, M. and Miller, M.C., 1997. Glacial and postglacial pollen records from the Ecuadorian Andes and Amazon. Quat. Res. 48, pp. 69-78.

Cross, S.L., Baker, P.A., Seltzer, G.O., Fritz, S.C. and Dunbar, R.B., 2001. Late Quaternary climate and hydrology of tropical South America inferred from an isotopic and chemical model of Lake Titicaca, Bolivia and Peru. Quat. Res. 56, pp. 1-9.

Curtis, S. and Hastenrath, S., 1999. Trends of upper-air circulation and water vapour over equatorial South America and adjacent oceans. Int. J. Climatol. 19, pp. 863-876.

Dejoux, C., Iltis, A.E., 1992. Lake Titicaca: A Synthesis of Limnological Knowledge. Kluwer Academic, Dordrecht, 573 pp.

Ellenberg, H., 1975. Man's influence on tropical mountain ecosystems in South America. J. Ecol. 67, pp. 401-416.

Faegri, K., Iversen, J., 1989. Textbook of Pollen Analysis. Wiley, Chichester, 340 pp. 
Fiedel, S.J., 1987. Prehistory of the Americas. Cambridge University Press, Cambridge, 386 pp.

Fritz, S.L., Metcalfe, S.E., Dean, W., 2001. Holocene climate patterns in the Americas inferred from paleolimnological records. In: Markgraf, V. (Ed.), Interhemispheric Climate Linkage. Academic Press, San Diego, CA, pp. 241-263.

Graf, K., 1981. Palynological investigations of two postglacial peat bogs near the boundary of Bolivia and Peru. J. Biogeogr. 8, pp. 353-368.

Grimm, E., 1992. TILIA Software, Version 1.12. Illinios State University, Normal, IL.

Hansen, B.C.S. and Rodbell, D.T., 1995. A late-glacial/Holocene pollen record from the eastern Andes of Northern Peru. Quat. Res. 44, pp. 216-227.

Hansen, B.C.S., Seltzer, G.O. and Wright Jr., H.E., 1994. Late Quaternary vegetation change in the central Peruvian Andes. Palaeogeogr. Palaeoclimatol. Palaeoecol. 109, pp. 263-285.

Hansen, B.C.S., Wright, H.E. Jr., Bradbury, J.P., 1984. Pollen studies in the Junín area, Central Peruvian Andes. Bull. Geol. Soc. Am. 1454-1465.

Heine, J.T., 1993. A reevaluation of the evidence for a Younger Dryas climatic reversal in the tropical Andes. Quat. Sci. Rev. 12, pp. 769-779.

Helmens, K.F. and Kuhry, P., 1986. Middle and late Quaternary vegetational and climatic history of the Paramo de Agua Blanca (Eastern Cordillera, Colombia). Palaeogeogr. Palaeoclimatol. Palaeoecol. 56, pp. 291-335.

Heusser, C.J., 1971. Pollen and Spores of Chile. Modern types of the Pteridophyta, Gymnospermae and Angiospermae. University of Arizona Press, Tucson, AZ, 167 pp.

Hill, M.O., 1979. DECORANA - A FORTRAN Program for Detrended Correspondence Analysis and Reciprocal Averaging. Ecology and Systematics, Cornell University, New York, 52 pp.

Holmgren, C.A., Betancourt, J.L., Rylander, K.A., Roque, J., Tovar, O., Zeballos, H., Linares, E. and Quade, J., 2001. Holocene vegetation history from fossil rodent middens near Arequipa, Peru. Quat. Res. 56, pp. 242-251.

Hooghiemstra, H., 1983. Pollen morphology of the Plantago species of the Colombian Andes and its application to fossil material. Rev. Acad. Colomb. Ci. Exactas Fis. Nat. 15, pp. 41-66.

Hooghiemstra, H., 1984. Vegetational and Climatic History of the High Plain of Bogota, Colombia: A Continuous Record of the Last 3.5 Million Years. Gantner Verlag, Vaduz, 368 pp.

Hooghiemstra, H., 1989. Quaternary and upper-Pliocene glaciations and forest development in the tropical Andes: Evidence from a long high-resolution pollen re- cord from the sedimentary basin of Bogota, Colombia. Palaeogeogr. Palaeoclimatol. Palaeoecol., pp. 11-26.

Hostetler, S.W. and Mix, A.C., 1999. Reassessment of iceage cooling of the tropical ocean and atmosphere. $\mathrm{Na}$ ture 399, pp. 673-676.

Klink, C., Aldenderfer, M., 1996. Archaic period settlement on the Altiplano: comparison of two recent surveys in the southwestern Lake Titicaca basin. 24th Midwest Conference on Andean and Amazonian Archaeology and Ethnohistory, Beloit, WI.

Kuhry, P., 1988. Palaeobotanical-Palaeoecological Studies of Tropical High Andean Peatbog Sections (Cordillera Oriental, Colombia). Dissertationes Botanicae, University of Amsterdam, Amsterdam.

Markgraf, V., D’Antoni, H.L., 1978. Pollen and Spores of Argentina. University of Arizona, Tucson, AZ, 208 pp.

Markgraf, V., 1980. Pollen dispersal in a mountain area. Grana 19, pp. 127-146.

McCune, B., Mefford, M.J., 1999. PC_ORD. Multivariate Analysis of Ecological Data. MJM Software Design, Gleneden Beach, OR.

Mix, A.C., Morey, A.E., Pisias, N.G. and Hostetler, S.W., 1999. Foraminiferal faunal estimates of paleotemperature: Circumventing the no-analog problem yields cool ice age tropics. Paleoceanography 14, pp. 350-359.

Moreno, P.I., 2000. Climate, fire and vegetation between about 13,000 and $9200{ }^{14} \mathrm{C}$ yr B.P. in the Chilean Lake District. Quat. Res. 54, pp. 81-89.

Moreno, P.I., Jacobson, G.L., Andersen, B.G., Lowell, T.V. and Denton, G.H., 1999. Vegetation and climate changes during the last glacial maximum and the last termination in the Chilean Lake District: A case study from Canal de la Puntilla ( $\left.41^{\circ} \mathrm{S}\right)$. Geogr. Ann. 81A, pp. 285-311.

Piperno, D.R. and Stothert, K.E., 2003. Phytolith evidence for early Holocene Cucurbita domestication in Southwest Ecuador. Science 299, pp. 1055-1057.

Roche, M.A., Bourges, J.C., Mattos, R., 1992. Climatology and hydrology of the Lake Titicaca basin. In: Dejoux, C., Iltis, A. (Eds.), Lake Titicaca: A Synthesis of Limnological Knowledge. Kluwer Academic, Boston, MA, pp. 63-83.

Rodbell, D.T., 1993. The timing of the last deglaciation in Cordillera Oriental, Northern Peru based on glacial geology and lake sedimentology. Bull. Geol. Soc. Am. 105, pp. 923-934.

Rodbell, D.T. and Seltzer, G.O., 2000. Rapid ice margin fluctuations during the Younger Dryas in the tropical Andes. Quat. Res. 54, pp. 328-338.

Rodbell, D.T., Seltzer, G.O., Anderson, D.M., Abbott, M.B., Enfield, D.B. and Newman, J.H., 1999. An 15,000-year record of El Niño-driven alluviation in southwestern Ecuador. Science 283, pp. 516-520. 
Rowe, H.D., Dunbar, R.B., Mucciarone, D.A., Seltzer, G.O., Baker, P.A. and Fritz, S., 2002. Insolation, moisture balance and climate change on the South American Altiplano since the Last Glacial Maximum. Clim. Change 52, pp. 175-199.

Salgado-Labouriau, M.L. and Rinaldi, M., 1990. Palynology of Gramineae of Venezuelan mountains. Grana 29, pp. 129-138.

Salgado-Labouriau, M.L., Rull, V., Schubert, Z.C. and Valastro, S.Jr., 1988. The establishment of vegetation after late Pleistocene deglaciation in the Paramo de Miranda, Venezuelan Andes. Rev. Palaeobot. Palynol. 55, pp. 5-17.

Salgado-Labouriau, M.L., Schubert, C. and Valastro, S.Jr., 1977. Paleoecologic analysis of a Late Quaternary terrace from Mucubaji, Venezuelan Andes. J. Biogeogr. 4, pp. 313-325.

Sandweiss, D.H., Richardson, J.B.I., Reitz, E.J., Rollins, H.B. and Maasch, K.A., 1996. Geoarchaeological evidence from Peru for a 5000 years B.P. onset of El Niño. Science 273, pp. 1531-1533.

Seltzer, G.O., 1990. Recent glacial history and paleoclimate of the Peruvian-Bolivian Andes. Quat. Sci. Rev. 9, pp. 137-152.

Seltzer, G.O., Cross, S., Baker, P., Dunbar, R. and Fritz, S., 1998. High-resolution seismic reflection profiles from Lake Titicaca, Peru/Bolivia. Evidence for Holocene aridity in the tropical Andes. Geology 26, pp. 167-170.

Seltzer, G.O., Rodbell, D.T., Baker, P.A., Fritz, S.C., Tapia, P.M., Rowe, H.D. and Dunbar, R.B., 2002. Early warming of tropical South America at the last glacialinterglacial transition. Science 296, pp. 1685-1686.

Seltzer, G.O., Rodbell, D.T. and Burns, S., 2000. Isotopic evidence for late Quaternary climatic change in tropical South America. Geology 28, pp. 35-38.

Stuiver, M. and Reimer, P.J., 1993. Extended ${ }^{14} \mathrm{C}$ database and revised CALIB radiocarbon calibration program. Radiocarbon 35, pp. 215-230.

Sylvestre, F., Servant, M., Servant-Vildary, S., Causse, C., Fournier, M. and Ybert, J.-P., 1999. Lake level chronology on the southern Bolivian Altiplano (18-23ㅇ) during Late-glacial time and the early Holocene. Quat. Res. 51, pp. 54-66.

Ter Braak, C.J.F., 1988. CANOCO - A FORTRAN Program for Canonical Community Ordination by [Partial] [Detrended] [Canonical] Correspondence Analysis, Principal Components Analysis and Redundancy Analysis, Version 2.1. Agricultural Mathematics Group, Wageningen.

Thompson, L.G., Davis, M.E., Mosley-Thompson, E., Sowers, T.A., Henderson, K.A., Zagorodnov, V.S.,
Lin, P.-N., Mikhalenko, V.N., Campen, R.K., Bolzan, J.F., Cole-Dai, J. and Francou, B., 1998. A 25,000-year tropical climate history from Bolivian ice cores. Science 282, pp. 1858-1864.

Thompson, L.G., Mosley-Thompson, E., Davis, M.E., Lin, P.-N., Henderson, K.A., Cole-Dai, J., Bolsan, J.F. and Liu, K.G., 1995. Late glacial stage and Holocene tropical ice core records from Huascaran, Peru. Science 269, pp. 46-50.

Van der Hammen, T., 1974. The Pleistocene changes of vegetation and climate in tropical South America. $J$. Biogeogr. 1, pp. 3-26.

Van der Hammen, T., Barelds, J., De Jong, H. and De Veer, A.A., 1981. Glacial sequence and environmental history in the Sierra Nevada del Cocuy (Colombia). Palaeogeogr. Palaeoclimatol. Palaeoecol. 32, pp. 247-340.

Van der Hammen, T., González, E., 1959. Historia de clima y vegetación del Pleistocene Superior y del Holoceno de la Sabana de Bogotá y alrededeores, Dept. Cundinamarca. Official Report of the Servicio Geologico Nacional, Bogotá.

Van der Hammen, T. and Hooghiemstra, H., 1995. The El Abra stadial, a Younger Dryas equivalent in Colombia. Quat. Sci. Rev. 14, pp. 841-851.

Van Geel, B. and Van der Hammen, T., 1973. Upper Quaternary vegetation and climatic sequence of the Fuquene area (Eastern Cordillera, Colombia). Palaeogeogr. Palaeoclimatol. Palaeoecol. 14, pp. 9-92.

Wirrmann, D., Mourguiart, P. and De Oliveira Almeida, L.F., 1988. Holocene sedimentology and ostracods distribution in Lake Titicaca - Paleohydrological interpretations. Quat. S. Am. Antarct. Penins. 6, pp. 89-128.

Wirrmann, D., Ybert, J.-P., Mourguiart, P., 1992. A 20,000 years paleohydrological record from Lake Titicaca. In: Dejoux, C., Iltis, A. (Eds.), Lake Titicaca: A Synthesis of Limnological Knowledge. Kluwer Academic, Boston, MA, pp. 40-48.

Wright Jr., H.E., Seltzer, G.O. and Hansen, B.C.S., 1989. Glacial and climatic history of the Central Peruvian Andes. Natl. Geogr. Res. 5, pp. 439-445.

Ybert, J.-P., 1988. Apports de la palynologie á la connaissance de l'histoire du lac Titicaca (Bolivie-Pérou) au cours du Quaternaire récent. Inst. Fr. Ponichéry Trav. Sec. Sci. Tech. XXV, pp. 139-150.

Ybert, J.P., 1992. Ancient lake environments as deduced from pollen analysis. In: DeJoux, C., Iltis, A. (Eds.), Lake Titicaca. A Synthesis of Limnological Knowledge. Kluwer Academic, Boston, MA, pp. 49-62. 